\title{
PREDICTIVE MARKER(S) OF SHORT-TERM PROGNOSIS AND MORTALITY RISK IN TRAUMATIC ACUTE SUBDURAL HEMATOMA PATIENTS AND STROKE PATIENTS AFTER DECOMPRESSIVE CRANIECTOMY
}

\author{
Travmatik Akut Subdural Hematom ve Inmelerde Dekompresif Kraniektomi Sonrası Kisa \\ Dönem Prognoz ve Mortalite Riskinin Olası Belirteçleri
}

\author{
Mustafa ÖĞDEN ${ }^{1}$ (D), Bahar SAY ${ }^{\text {(D) }}$, Ulaş YÜKSEL ${ }^{1}$ (D), Alemiddin ÖZDEMİ ${ }^{1}$ (D), \\ Süleyman AKKAYA ${ }^{1}$, Bülent BAKAR ${ }^{1}$ (D)
}

\author{
${ }^{1}$ Kırıkkale Üniversitesi, Tip Fakültesi, Nöroşirurji A.D., Yahşihan, KIRIKKALE, TÜRKIYYE \\ ${ }^{2}$ Kırıkkale Üniversitesi, Tip Fakültesi, Nöroloji A.D., Yahşihan, KIRIKKALE, TÜRKIYE
} \begin{abstract}
ÖZ

Objective: Decompressive craniectomy can reduce mortality in selected patients with stroke and traumatic acute subdural hematoma. This study aimed to explore predictive markers for short-term prognosis and mortality risk in patients who underwent decompressive craniectomy due to traumatic acute subdural hematoma or malignant middle cerebral artery occlusion using clinical, radiological, and routine blood biochemistry findings.

Material and Methods: Eleven traumatic acute subdural hematoma patients and 11 stroke patients were included in this study. On admission to hospital, for each patient, age, gender, Glasgow Coma Scale scores, anisocoria, time elapsed for decompressive craniectomy administration, midline shift level, duration of stay in Intensive Care Unit and in hospital, and Glasgow Outcome Scale scores on discharge from hospital and blood biochemistry findings were examined.

Results: The Glasgow Outcome Scale score was found 3.5 (2-5) in surviving patients and it was seen that short-term prognosis of patients could be associated with lymphocyte, neutrophil, and platelet count, neutrophil-lymphocyte ratio, and serum C-reactive protein level. However, mortality rate in both groups was found $77.2 \%$, and it was thought that age, leukocyte, monocyte and platelet count, and serum blood urea nitrogen level could be associated with mortality risk.

Conclusion: As a result, it could be said that decompressive craniectomy could not reduce mortality risk in both groups. However, it was suggested that lymphocyte, neutrophil, and platelet counts, neutrophil-lymphocyte ratio, and serum Creactive protein levels could be assumed as markers for shortterm prognosis. Furthermore, it was concluded that age, leukocyte, monocyte, and platelet counts, and serum blood urea

Amaç: Dekompresif kraniektomi, inme ve travmatik akut subdural hematom (TASH) bulunan seçilmiş hastalarda mortaliteyi azaltabilir. Bu çalışma, klinik, radyolojik ve rutin kan biyokimya bulguları kullanarak travmatik akut subdural hematom veya malign orta serebral arter oklüzyonu nedeniyle dekompresif kraniektomi uygulanan hastalarda kısa vadeli prognoz ve mortalite riski için öngörücü belirteçleri araştırmayı amaçladı.

Gereç ve Yöntemler: $\mathrm{Bu}$ çalışmaya 11 travmatik akut subdural hematom hastas1 ve 11 inme hastas1 dahil edildi. Hastaneye kabulde, her hasta için yaş, cinsiyet, Glasgow Koma Skalası skorları, anizokori, dekompresif kraniektomi uygulaması için geçen süre, orta hat kayma seviyesi, Yoğun Bakım Ünitesinde ve hastanede kalış süresi ve hastaneden taburculukta Glasgow Sonuç Ölçeği puanları ve kan biyokimya bulguları incelendi.

Bulgular: Yaşayan hastalarda Glasgow Sonuç Ölçeği skoru 3.5 (2-5) bulundu ve hastaların kısa dönem prognozunun lenfosit, nötrofil ve trombosit sayısı, nötrofil-lenfosit oranı ve C-reaktif protein ile ilişkili olabileceği görüldü. Ancak her iki grupta da ölüm oranı \% 77.2 olarak bulundu ve yaş, lökosit, monosit ve trombosit sayıs ile serum kan idrar nitrojen düzeyinin ölüm riski ile ilişkili olabileceği bulundu.

Sonuç: Sonuç olarak dekompresif kraniektominin her iki grupta da mortalite riskini azaltamadığı düşünüldü. Ancak lenfosit, nötrofil ve trombosit sayıları, nötrofil-lenfosit oranı ve serum C-reaktif protein düzeylerinin kısa dönem prognoz için öngörücü belirteç olarak kabul edilebileceği savunuldu. Ayrıca mortalite riskini öngörebilmede yaş, lökosit, monosit ve trombosit sayıları ile serum nitrojen düzeylerinin belirteçler olabileceği sonucuna varıldı.
\end{abstract} nitrogen levels could be predictors of mortality risk.

Keywords: Decompressive craniectomy, traumatic acute subdural hematoma, stroke, short-term prognosis, mortality risk
Anahtar Kelimeler: Dekompresif kraniektomi, travmatik akut subdural hematom, inme, kisa dönem prognoz, mortalite riski 


\section{INTRODUCTION}

Decompressive craniectomy (DC) is still one of the most important treatment regimens applied in patients with traumatic brain injury (TBI) or stroke (1-3). DC can reduce mortality and control intracranial pressure (ICP) as well as improving pressure-volume compensatory reserve and oxygen delivery to brain cells (4). Mortality risk in these patients is associated with the patient's age, type and severity of the injury, the time elapsed to surgery, and duration of postoperative intensive care stay (4-7). Currently, in order to improve the neurological picture and to decrease the mortality rates, discussion for the necessity of determining the predictive factors for patient prognosis has begun in the literature $(5,8)$. Many prognostic factors have been examined in many studies, but different results have been reported $(9,10)$.

This study aimed to explore the predictive markers for the short-term prognosis and mortality risk in patients who underwent DC due to the traumatic acute subdural hematoma (TASH) or middle cerebral artery occlusion (MCAO) using their clinical, radiological, and blood biochemistry findings obtained from their admission to the hospital.

\section{MATERIALS AND METHODS}

\section{Patient Groups}

Approval for this study was granted by the Local Clinical Research Ethics Committee (Kırıkkale University Ethics Committee of Non-Interventional Clinical Research, date: 26.08.2020; issue number: 2020.08.03). non-interventional ethics committee

The data of patients who were brought to the Emergency Department (ED) for reasons of a "fall from a height", "traffic accident" and "stroke" between January 2015 and June 2020 were examined. Then, patients who underwent unilateral DC due to the MCAO or TASH were included in this study. The patients were excluded from this study if data were incomplete, if they were dead in ED, if they had accompanying major organ injuries, if they had another type of intracranial hemorrhage, if they had trauma not related to falling from a height or traffic accident, if a different surgical technique (bifrontal decompressive craniectomy, etc.) was performed, or if they were in the pediatric age group $(<16$ years)

Following the first CT scan, patients underwent control brain CT scanning twice at three-hour intervals, and at the end of 24 hours in both groups (10). Until the surgical treatment was applied, patients received supportive treatment including bed height, hyperosmolar treatment, administration of the sedation anesthesia and/or cerebrospinal fluid (CSF) drainage when necessary.

The patients were grouped according to the etiology as follows:

TASH-OP group (consisted of the operated patients due to the TASH, $\mathrm{n}=11$ ).

STROKE-OP group (consisted of the operated patients due to the MCAO, $\mathrm{n}=11$ )

The patients were also separated into 2 groups according to the mortality rate:

SURVIVED group (consisted of the patients discharged from the hospital, $n=6$ )

NON-SURVIVED group (consisted of the patients who died in the hospital following the surgical intervention, $\mathrm{n}=16)$

\section{Materials}

On admission to hospital, age, gender, Glasgow Coma Scale (GCS) scores, presence of the anisocoria, the time elapsed for DC (very early surgery $(<6$ hours after injury), early surgery (6-24 hours after injury), and late surgery ( $>24$ hours after injury), duration of stay in Intensive Care Unit (ICU), duration of stay in the hospital, and Glasgow Outcome Scale (GOS) scores were recorded for each patient $(16,17)$. The brain CT images obtained on admission to hospital and follow-up period were examined and the midline shift level (MLS), DC site, and craniectomy area were recorded (11-14). 


\section{Biochemical Analysis}

The blood biochemistry results were examined in blood samples obtained from the patients during admission to hospital. The hemoglobin level (reference range: 10-18 $\mathrm{g} / \mathrm{dL}$ ), leukocyte (reference range: 4400-11300 uL), neutrophil (reference range: 110-9600 uL), lymphocyte (reference range: 500-6000 uL), monocyte (reference range: 100-1400 uL), eosinophil (reference range: 0$1000 \mathrm{uL}$ ), basophil (reference range: 0-300 uL), and platelet (reference range: 150,000-500,000 uL) count values were determined with an analysis device (Mindray BC-6800, China). Serum glucose (reference range: 74-109 $\mathrm{mg} / \mathrm{dL}$ ), blood urea nitrogen (BUN) (reference range: 17-43 $\mathrm{mg} / \mathrm{dL}$ ), creatinine (reference range: $0.84-1.24 \mathrm{mg} / \mathrm{dL}$ ), alanine aminotransferase (ALT) (reference range: 5-41 U/L), aspartate aminotransferase (AST) (reference range: 5-40 U/L), sodium (reference range: 136-146 mmol/L), potassium (reference range: $3.5-5.1 \mathrm{mmol} / \mathrm{L}$ ), and C-reactive protein (CRP) (reference range: $0.15-5 \mathrm{mg} / \mathrm{dL}$ ) levels were obtained using original kits (Roche) on an automatic device (Roche Diagnostic COBAS c501).

\section{Surgery}

Under general anesthesia, a wide frontotemporoparietal DC was administered on the side of the TASH or stroke in all patients whose MLS was $>5 \mathrm{~mm}$; and/or hematoma thickness was $>10 \mathrm{~mm}$ on CT images; and/or when GCS score decreased higher than 2 units; and/or when anisocoria was detected $(10,15)$. The dura mater was appropriately opened in all patients, and in TASH patients, the hematoma was drained and the bleeding focus was cauterized. Lobectomy was not performed on any patient. Following hemostasis, duraplasty was applied with an autogenous graft taken from the galea or tensor fascia lata. The bone flap was left over the abdominal fascia or tensor fascia lata, and the surgical areas were closed anatomically, and the operation was terminated (Figure 1 and 2). Then, intubated patients were observed for at least 48 hours in ICU under sedation anesthesia provided by midazolam
(Dormicum ${ }^{\circledR}$, Roche). The craniectomy area was measured and recorded on CT images obtained postoperatively (Figure 3) $(13,14)$.

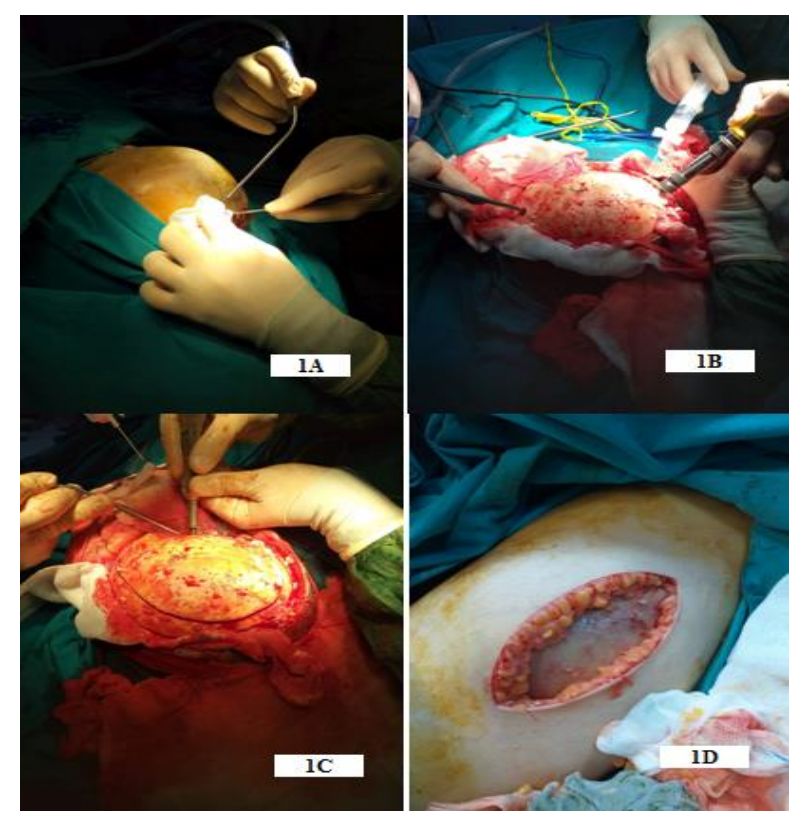

Figure 1: During decompressive craniectomy, a wide craniectomy was performed on the side of the traumatic acute subdural hematoma or stroke $(\mathbf{1 A}, \mathbf{1 B}, \mathbf{1 C})$; and because the brain was swollen in all operated patients, the bone flap was left over the abdominal fascia or over the tensor fascia lata from which the dural graft had been previously taken (1D).

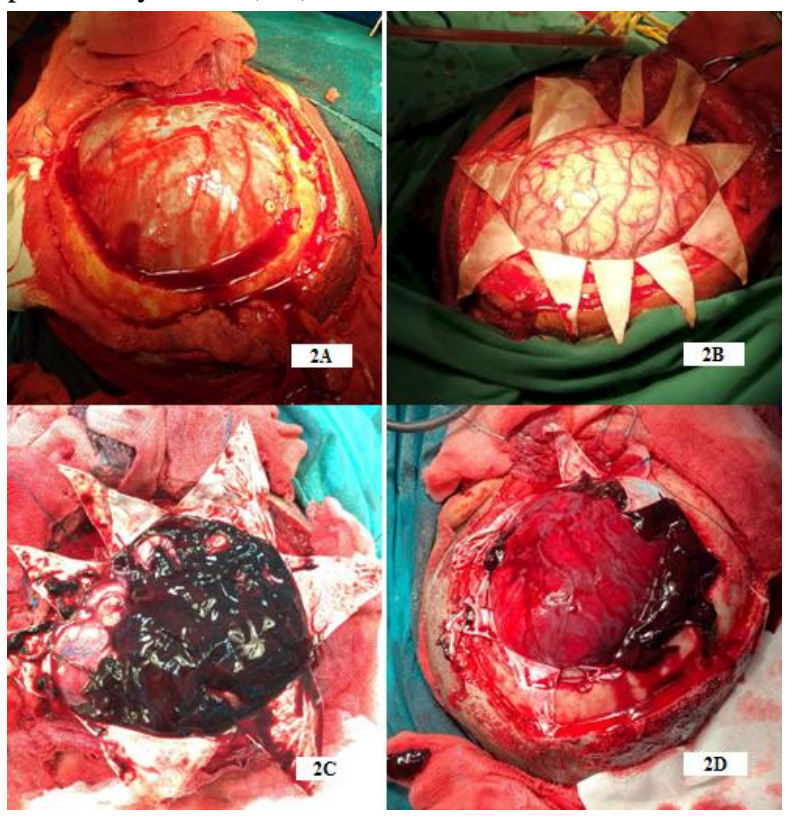

Figure 2: After a wide craniectomy was performed (2A); the dura mater was opened appropriately in both groups' patients $(\mathbf{2 B}, \mathbf{2 C})$; and in traumatic acute subdural hematoma patients, the hematoma was drained as much as possible and hemostasis was obtained (2D). 


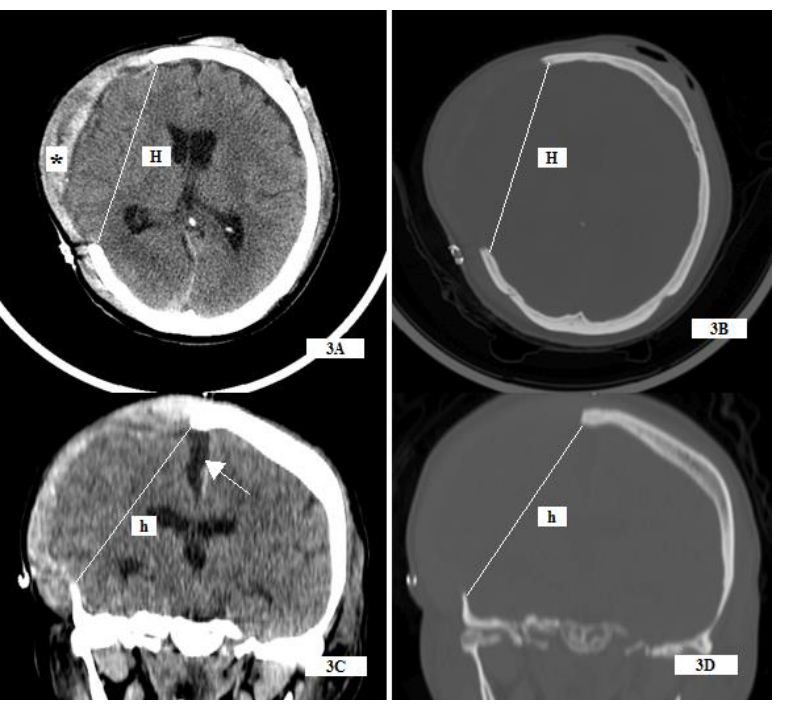

Figure 3: The area of the right craniectomy was approximately measured in sagittal (3A, 3B) and axial (3C, 3D) brain CT images of a patient with acute subdural hematoma by the following equation described in the literature: Area $(\mathrm{cm} 2)=H^{*} h^{*} \pi$. In this equation, the " $\mathrm{H}$ " value is the anteroposterior diameter of the bone flap and the " $h$ " value is the diameter, perpendicular to the " $\mathrm{H}$ " value, from the superior craniectomy margin to the inferior margin in centimeters. In this image, a galeal hematoma (with asterix) and cerebrospinal fluid entrapment (with arrow) which developed as complications related to the decompressive craniectomy also can be seen.

\section{Statistical Analysis}

Nonparametric findings were analyzed using MannWhitney U test. Parametric variables were analyzed using Independent Samples t-test. To determine the correlation between the parameters of the patients Spearman's rho Correlation test was used. The ROCCurve test was used to explore the predictive parameters on prognosis and mortality risk. Additionally, the Logistic Regression test and Likelihood Ratio test were used to determine which of these parameters could be the "best parameter". Finally, the direction and strength of the association between DC and complication risk and mortality risk were quantified using Odds Ratio (OR) test. $\mathrm{p}<0.05$ was considered statistically significant.

\section{RESULTS}

In this study, 22 patients (male=13, female=9) were included. External ventricular drainage catheter was inserted into 2 patients who developed hydrocephalus after DC, and it was observed that hydrocephalus improved without ventriculoperitoneal shunt administration. After DC, cerebrospinal fluid (CSF) entrapment determined in 4 patients did not require surgical drainage. In one patient, a one-sided epidural hematoma developed and was evacuated. Sixteen (73\%) patients (female $=8$, male $=8$ ) died after DC.

Age, gender, comorbidity, the time elapsed for DC, leukocyte, potassium and AST values were different between TASH-OP and STROKE-OP groups $(\mathrm{p}<0.05)$ (Table 1).

Comorbidity, hemoglobin, leukocyte, neutrophil, and monocyte values, duration of stay in ICU and duration of stay in hospital were different between male and female patients $(\mathrm{p}<0.05)$ (Table 2$)$.

Age, lymphocyte, monocyte and platelet values were found different between NON-SURVIVED and SURVIVED groups $(\mathrm{p}<0.05)$ (Table 3$)$.

The correlation analysis performed for the data of all patients revealed a positive correlation between the age and comorbidity $(\mathrm{r}=0.605, \mathrm{p}=0.003), \mathrm{BUN}$ values $(\mathrm{r}=0.426, \mathrm{p}=0.048)$ and time elapsed for DC $(\mathrm{r}=0.531$, $\mathrm{p}=0.011$ ), and a negative correlation between age and leucocyte $(\mathrm{r}=-0.476, \mathrm{p}=0.025)$, monocyte values $(\mathrm{r}=$ $0.446, \mathrm{p}=0.037)$ and mortality rate $(\mathrm{r}=-0.483, \mathrm{p}=0.023)$. Gender was positively correlated with comorbidity $(\mathrm{r}=0.436, \mathrm{p}=0.043)$, and negatively correlated with length of stay in ICU ( $r=-0.474, p=0.026)$, length of stay in hospital $(r=-0.474, p=0.026)$, and hemoglobin $(r=-$ 0.496, $\mathrm{p}=0.019)$, leukocyte $(\mathrm{r}=-0.561, \mathrm{p}=0.007)$, neutrophil ( $\mathrm{r}=-0.444, \mathrm{p}=0.038)$, and monocyte values $(\mathrm{r}=-0.438, \mathrm{p}=0.042)$. A negative correlation was found between the GCS scores and serum glucose values ( $\mathrm{r}=$ $0.463, \mathrm{p}=0.030$ ). GOS scores were positively correlated with lymphocyte $(r=0.426, p=0.048)$, and platelet values $(\mathrm{r}=0.644, \mathrm{p}=0.001)$, and negatively correlated with age 
$(\mathrm{r}=-0.508, \mathrm{p}=0.016)$. A negative correlation was observed between MLS and sodium values ( $\mathrm{r}=-0.434$, $\mathrm{p}=0.044)$.

Time elapsed for DC was positively correlated with comorbidity $\quad(\mathrm{r}=0.681, \quad \mathrm{p}<0.001), \quad$ PLR $\quad(\mathrm{r}=0.530$, $\mathrm{p}=0.011)$ and potassium values $(\mathrm{r}=0.507, \mathrm{p}=0.016)$, and negatively correlated with lymphocyte ( $\mathrm{r}=-0.557$, $\mathrm{p}=0.007)$, basophil $(\mathrm{r}=-0.432, \mathrm{p}=0.045)$ and AST values ( $\mathrm{r}=-0.633, \mathrm{p}=0.002)$. Comorbidity was negatively correlated with leukocyte $(\mathrm{r}=-0.423, \mathrm{p}=0.014)$ and AST values $(r=-0.430, p=0.046)$, and positively correlated with potassium values $(\mathrm{r}=0.426, \mathrm{p}=0.048)$. While CRP value was positively correlated with neutrophil $(\mathrm{r}=0.539, \mathrm{p}=0.010)$ and NLR values $(\mathrm{r}=0.516, \mathrm{p}=0.014)$, and negatively correlated with lymphocyte values ( $\mathrm{r}=-$ 0.427, $\mathrm{p}=0.047$ ). Mortality rate was negatively correlated with platelet count values $(\mathrm{r}=-0.660, \mathrm{p}=$ $0.001)$.

The ROC-Curve analysis revealed that leukocyte (area $=0.107, \mathrm{p}=0.038$, cut-off value $<8625 / \mathrm{uL}, 75 \%$ sensitivity, $86 \%$ specificity) and neutrophil count results (area $=0.927, \mathrm{p}=0.003$, cut-off value $<5750 / \mathrm{uL}, 75 \%$ sensitivity, $86 \%$ specificity) could predict the complication risk. Furthermore, age (area $=0.188$, $\mathrm{p}=0.027$, cut-off value $>37$-year, $67 \%$ sensitivity, $88 \%$ specificity), and platelet count result (area $=0.927$, $\mathrm{p}=0.003$, cut-off value $<291000 \mathrm{uL}, 100 \%$ sensitivity, $81 \%$ specificity) could predict the mortality risk. However, Logistic Regression analysis showed that no parameter could be the "best marker" in predicting mortality risk and complication risk. Likelihood Ratio test performed for GOS scores revealed that age, and platelet count value could be the "best markers" for the prediction the short-term prognosis $(\mathrm{p}<0.05)$ (Table 4, Figure 4). On the other hand, Odds Ratio test results revealed that if anisocoria was detected, it was associated with more than one-fold risk of complication $(\mathrm{OR}=1.75,95 \% \mathrm{CI}=1.21-2.54)$ and mortality $(\mathrm{OR}=1.40$, 95\% CI=1.07-1.84) (Table 4, Figure 4).
The correlation analysis applied to the data of the patients in the TASH-OP group revealed a negative correlation between gender and hemoglobin ( $r=-0.674$, $\mathrm{p}=0.023)$ and neutrophil values $(\mathrm{r}=-0.674, \mathrm{p}=0.024)$. GOS scores were positively correlated with lymphocyte values $(r=0.749, p=0.008)$, and negatively correlated with NLR values $(r=-0.679, p=0.022)$. Time elapsed for DC was positively correlated with NLR ( $\mathrm{r}=0.679$, $\mathrm{p}=0.022)$ and PLR values $(\mathrm{r}=0.679, \mathrm{p}=0.022)$, and negatively correlated with lymphocyte ( $\mathrm{r}=-0.679$, $\mathrm{p}=0.022)$, eosinophil $(\mathrm{r}=-0.632, \mathrm{p}=0.037)$, and basophil values $(r=-0.635, p=0.036)$. Length of stay in hospital was positively correlated with duration of stay in ICU $(\mathrm{r}=0.620, \mathrm{p}=0.042)$, and negatively correlated with CRP value $(\mathrm{r}=-0.793, \mathrm{p}=0.004)$. The mortality rate was positively correlated to the lymphocyte value $(r=0.775$, $\mathrm{p}=0.005)$.

ROC-Curve analysis revealed that lymphocyte (area $=0.000, \mathrm{p}=0.014$, cut-off value $<4910 \mathrm{uL}, 87 \%$ sensitivity, $100 \%$ specificity), and NLR values (area $=0.958, \mathrm{p}=0.025$, cut-off value $>74.74,100 \%$ sensitivity, $67 \%$ specificity) could predict mortality risk. However, the regression analysis showed that those parameters could not be the "best marker" in predicting the mortality risk in TASH patients. On the other hand, Odds Ratio test results revealed that if anisocoria was detected $\quad(\mathrm{OR}=2.00,95 \% \quad \mathrm{CI}=1.08-3.72), \quad$ it was associated with more than two-fold risk of complication (Table 4, Figure 4).

Correlation analysis applied to the data of patients in the STROKE-OP group revealed a positive correlation between the age and comorbidity $(\mathrm{r}=0.671, \mathrm{p}=0.024)$ and a negative correlation between age and hemoglobin values $(\mathrm{r}=-0.565, \mathrm{p}=0.028)$, GOS scores $(\mathrm{r}=-0.667$, $\mathrm{p}=0.025)$ and mortality rate $(\mathrm{r}=-0.645, \mathrm{p}=0.032)$. Gender was positively correlated with glucose values $(r=0.873$, $\mathrm{p}=0.001$ ), and negatively correlated with hemoglobin values $(r=-0.719, p=0.013)$, length of stay in ICU ( $r=-$ 0.717, $\mathrm{p}=0.013)$ and length of stay in hospital $(\mathrm{r}=-0.779$, $\mathrm{p}=0.005)$. GCS scores were positively correlated with 
comorbidity ( $\mathrm{r}=-0.682, \mathrm{p}=0.021)$, and MLS level value $(\mathrm{r}=-0.667, \mathrm{p}=0.025)$. Complication rates were positively correlated with time elapsed for DC application ( $\mathrm{r}=-$ 0.624, $\mathrm{p}=0.040)$, leukocyte $(\mathrm{r}=-0.657, \mathrm{p}=0.028)$, and neutrophil values $(\mathrm{r}=-0.657, \mathrm{p}=0.028)$. GOS scores were positively correlated with platelet values $(r=0.667$, $\mathrm{p}=0.025)$ and potassium values $(\mathrm{r}=0.667, \mathrm{p}=0.025)$. Time elapsed for DC was positively correlated with and neutrophil ( $\mathrm{r}=0.671, \mathrm{p}=0.024)$ and PLR values $(\mathrm{r}=0.671$, $\mathrm{p}=0.024)$. Length of stay in hospital was positively correlated with length of stay in ICU $(r=0.761$, $\mathrm{p}=0.007$ ). Mortality rates were positively correlated with platelet $(r=0.645, \mathrm{p}=0.032)$ and potassium values $(\mathrm{r}=0.645, \mathrm{p}=0.032)$.

ROC-Curve analysis revealed that age (area $=0.917$, $\mathrm{p}=0.041$, cut-off value $>59$-year-old, $88 \%$ sensitivity, $100 \%$ specificity), platelet (area $=0.083, \mathrm{p}=0.041$, cut-off value <189500 uL, 88\% sensitivity, 100\% specificity), and potassium values $($ area $=0.083, \mathrm{p}=0.041$, cut-off value $<4.21 \mathrm{mmol} / \mathrm{L}, 88 \%$ sensitivity, $100 \%$ specificity) could predict the mortality risk in short-term period. However, the regression analysis revealed that these parameters could not be "the best marker" to predict mortality risk in stroke patients (Table 4, Figure 4).
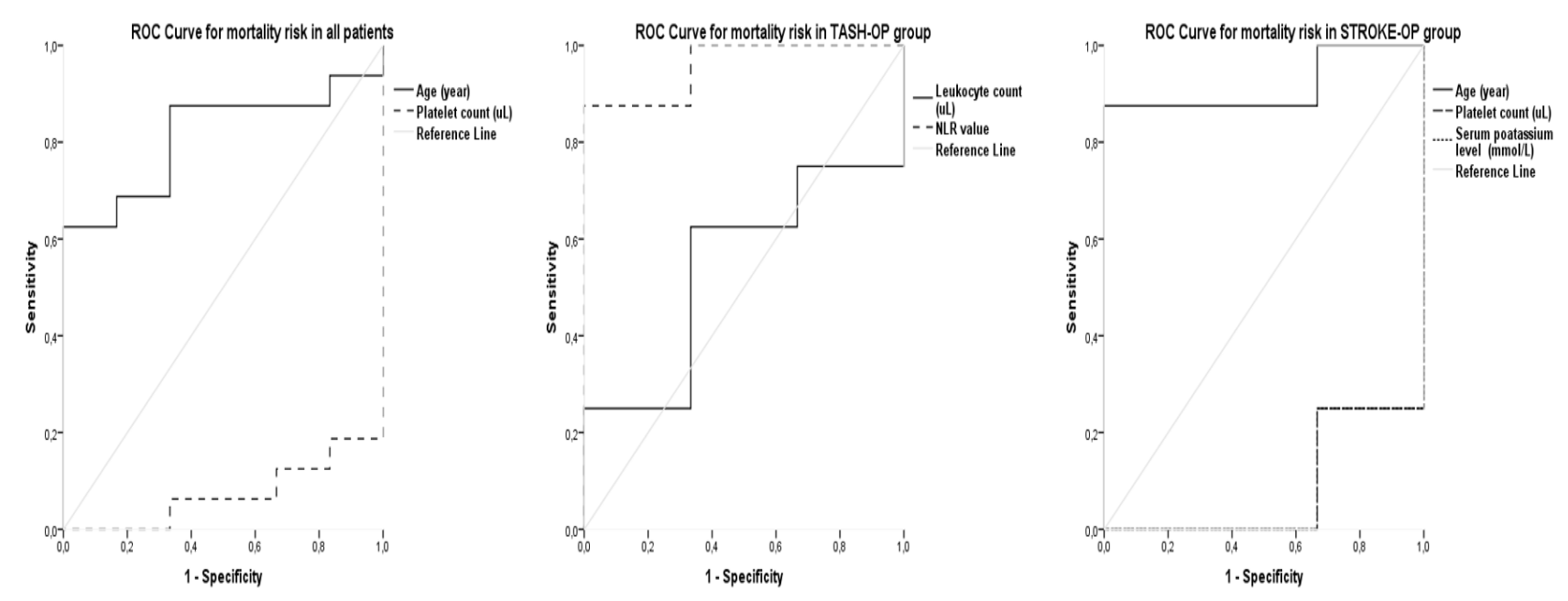

Figure 4: The ROC-Curve analysis revealed that patient's age and platelet count could predict mortality risk in both groups (5A), whereas the lymphocyte count and neutrophil-lymphocyte ratio (NLR) value could predict mortality risk in patients with acute subdural hematoma (5B), and patient's age, platelet count and serum potassium level values could predict mortality risk in stroke patients (5C). 
Table 1: Descriptive table for the demographic, radiological and biochemical findings of the TASH-OP group and STROKE-OP.

\begin{tabular}{|c|c|c|c|c|c|}
\hline \multirow[b]{3}{*}{ Variable } & & TASH-OP & STROKE-OP & \multirow[b]{3}{*}{$\mathbf{t} / \mathbf{Z} / \mathbf{X}^{2}$} & \multirow[b]{3}{*}{$\mathbf{p}$} \\
\hline & & $\begin{array}{c}\text { Mean } \pm \text { SD/ } \\
\text { Median (min-max) }\end{array}$ & $\begin{array}{c}\text { Mean } \pm \text { SD/ } \\
\text { Median (min-max) }\end{array}$ & & \\
\hline & & $\mathrm{n}(\%)$ & $\mathrm{n}(\%)$ & & \\
\hline Age (year) & & $44.82 \pm 21.76$ & $62.45 \pm 16.28$ & $-2.153 *$ & 0.044 \\
\hline \multirow[t]{2}{*}{ Gender $(1=.2=)$} & Male & $9(40.9 \%)$ & $4(18.2 \%)$ & $4.701+$ & $\mathbf{0 . 0 3 0}$ \\
\hline & Female & $2(9.1 \%)$ & $7(31.8 \%)$ & & \\
\hline \multirow[t]{2}{*}{ Comorbidity } & No & $11(11 \%)$ & $2(9.1 \%)$ & $15.231 \ddagger$ & $<0.001$ \\
\hline & Yes & $0(0.0 \%)$ & $9(40.9 \%)$ & & \\
\hline Glasgow Coma Scale score & & $4(3-13)$ & $6(4-10)$ & $-0.830 \dagger$ & 0.407 \\
\hline Midline shift level (mm) & & $8.50 \pm 4.27$ & $10.14 \pm 4.76$ & $-0.849 *$ & 0.406 \\
\hline \multirow[t]{2}{*}{ Pupillary dilatation } & No & $1(4.5 \%)$ & $0(0.0 \%)$ & $1.048+$ & 0.306 \\
\hline & Yes & $10(45.5 \%)$ & $11(50.0 \%)$ & & \\
\hline \multirow[t]{3}{*}{ Decision time of DC } & Very early & $8(36.4 \%)$ & $0(0.0 \%)$ & $12.788 t$ & 0.002 \\
\hline & Early & $1(4.5 \%)$ & $2(9.1 \%)$ & & \\
\hline & Late & $2(9.1 \%)$ & $9(40.9 \%)$ & & \\
\hline \multirow[t]{2}{*}{ DC site } & Left & $5(22.7 \%)$ & $6(27.3 \%)$ & $0.182 \ddagger$ & 0.670 \\
\hline & Right & $6(27.3 \%)$ & $5(22.7 \%)$ & & \\
\hline DC area $\left(\mathrm{cm}^{2}\right)$ & & $97.00(78-116)$ & $96(50-116)$ & $-0.296 \dagger$ & 0.767 \\
\hline \multirow[t]{2}{*}{ Complication related to DC } & No & $6(27.3 \%)$ & $7(31.8 \%)$ & $0.188 t$ & 0.665 \\
\hline & Yes & $5(22.7 \%)$ & $4(18.2 \%)$ & & \\
\hline Hemoglobin level (g/dL) & & $13.40 \pm 2.75$ & $14.29 \pm 1.48$ & $-0.948^{*}$ & 0.355 \\
\hline Leukocyte count (uL) & & $17013 \pm 5257.05$ & $11598 \pm 5118.96$ & $2.447 *$ & 0.024 \\
\hline Neutrophil count (uL) & & $12089 \pm 6418.22$ & $8130 \pm 4548.53$ & $1.669 *$ & 0.111 \\
\hline Lymphocyte count (uL) & & $3957 \pm 3137.69$ & $2627 \pm 969.04$ & $1.343 *$ & 0.194 \\
\hline Monocyte count (uL) & & $780 \pm 304.63$ & $521 \pm 300.55$ & $2.008 *$ & 0.058 \\
\hline Eosinophil count (uL) & & $127 \pm 132.14$ & $193 \pm 149.20$ & $-1.089 *$ & 0.289 \\
\hline Basophil count (uL) & & $56 \pm 30.09$ & $40 \pm 24.08$ & $1.408 *$ & 0.174 \\
\hline Platelet count (uL) & & $268636 \pm 83351.39$ & $289000 \pm 107475.58$ & $-0.497 *$ & 0.625 \\
\hline Neutrophil to lymphocyte ratio & & $5.50 \mathrm{~m}(074-73.74)$ & $3.03(1.26-13.25)$ & $-0.361 \dagger$ & 0.718 \\
\hline Platelet to lymphocyte ratio & & $60.29(2.20-773.97)$ & $92.67(53.20-619.23)$ & $-0.952 \dagger$ & 0.341 \\
\hline Glucose (mg/dL) & & $186.09 \pm 47.04$ & $173.91 \pm 54.66$ & $0.560^{*}$ & 0.582 \\
\hline Sodium (mmol/L) & & $139.27 \pm 6.68$ & $137.27 \pm 1.90$ & $0.955^{*}$ & 0.351 \\
\hline Potassium (mmol/L) & & $4.10 \pm 0.41$ & $4.74 \pm 0.52$ & $-3.222 *$ & 0.004 \\
\hline Blood urea nitrogen $(\mathrm{mg} / \mathrm{dL})$ & & $33.93 \pm 13.16$ & $32.24 \pm 11.96$ & $0.314 *$ & 0.757 \\
\hline Creatinin (mg/dL) & & $0.89(0.58-5.20)$ & $0.81(0.69-1.18)$ & $-0.164 \dagger$ & 0.870 \\
\hline Aspartate aminotransferase $(\mathrm{u} / \mathrm{L})$ & & $26.24(21.71-158)$ & $21.31(11.34-42.04)$ & $-2.134 \dagger$ & $\mathbf{0 . 0 3 3}$ \\
\hline Alanine aminotransferase $(\mathrm{u} / \mathrm{L})$ & & $22.39(10-132)$ & $18.45(10-45.49)$ & $-0.263 \dagger$ & 0.793 \\
\hline C-reactive protein $(\mathrm{mg} / \mathrm{dL})$ & & $16(0.01-250.77)$ & $14(0.56-40)$ & $-0.230 \dagger$ & 0.818 \\
\hline Duration of stay in ICU (day) & & $18(7-102)$ & $17(4-425)$ & $-0.690 \dagger$ & 0.490 \\
\hline Duration of stay in hospital (day) & & $25(12-102)$ & $20(5-425)$ & $-0.362 \dagger$ & 0.718 \\
\hline Glasgow Outcome Scale score & & $1(1-5)$ & $1(1-4)$ & $-0.126 \dagger$ & 0.900 \\
\hline \multirow[t]{2}{*}{ Mortality rate } & Survived & $3(13.6 \%)$ & $3(13.6 \%)$ & $0.000 \ddagger$ & 1.000 \\
\hline & Died & $8(36.4 \%)$ & $8(36.4 \%)$ & & \\
\hline
\end{tabular}

(*) Independent Samples t test; $(\dagger)$ Mann Whitney U test; and ( $\$)$ Pearson’s chi-square test, $p<0.05$ 
Table 2: Descriptive table for the demographic, radiological and biochemical findings of the MALE and FEMALE groups.

\begin{tabular}{|c|c|c|c|c|c|}
\hline Variable & & $\begin{array}{c}\text { MALE } \\
\text { Mean } \pm \text { SD/ } \\
\text { Median (min-max) } \\
\mathrm{n}(\%)\end{array}$ & $\begin{array}{c}\text { FEMALE } \\
\text { Mean } \pm \text { SD/ } \\
\text { Median (min-max) } \\
n(\%)\end{array}$ & $\mathbf{t} / \mathbf{Z} / \mathbf{X}^{2}$ & $\mathbf{p}$ \\
\hline Age (year) & & $51.38 \pm 21.04$ & $56.89 \pm 21.27$ & $-0.601 *$ & 0.555 \\
\hline \multirow[t]{2}{*}{ Comorbidity } & No & $10(45.5 \%)$ & $3(13.6 \%)$ & $4.180 \%$ & 0.041 \\
\hline & Yes & $3(13.6 \%)$ & $6(27.3 \%)$ & & \\
\hline Glasgow Coma Scale score & & $5(3-13)$ & $5(3-10)$ & $-0.101 \dagger$ & 0.919 \\
\hline Midline shift level (mm) & & $8.69 \pm 4.48$ & $10.22 \pm 4.62$ & $-0.778 *$ & 0.446 \\
\hline \multirow[t]{2}{*}{ Pupillary dilatation } & No & $1(4.5 \%)$ & $0(0.0 \%)$ & $0.725 t$ & 0.394 \\
\hline & Yes & $12(54.5 \%)$ & $9(40.9 \%)$ & & \\
\hline \multirow[t]{3}{*}{ Decision time of the DC } & Very early & $6(46.2 \%)$ & $2(9.1 \%)$ & $1.755 \$$ & 0.416 \\
\hline & Early & $2(9.1 \%)$ & $1(4.5 \%)$ & & \\
\hline & Late & $5(22.7 \%)$ & $6(27.3 \%)$ & & \\
\hline \multirow[t]{2}{*}{ DC site } & Left & $7(31.8 \%)$ & $4(18.2 \%)$ & $0.188 \$$ & 0.665 \\
\hline & Right & $6(27.3 \%)$ & $5(22.7 \%)$ & & \\
\hline DC diameter & & $97(50-116)$ & $96(71-116)$ & $-0.702 \dagger$ & 0.482 \\
\hline \multirow[t]{2}{*}{ Complication related to DC } & No & $7(31.8 \%)$ & $6(27.3 \%)$ & $0.362 \ddagger$ & 0.548 \\
\hline & Yes & $6(27.3 \%)$ & $3(13.6 \%)$ & & \\
\hline Hemoglobin level (g/dL) & & $14.70 \pm 1.74$ & $12.61 \pm 2.30$ & $2.434 *$ & 0.024 \\
\hline Leukocyte count (uL) & & $16740 \pm 5641.48$ & $10789 \pm 4021.58$ & $2.714^{*}$ & 0.013 \\
\hline Neutrophil count (uL) & & $12187 \pm 6169.13$ & $7108 \pm 3726.77$ & $2.198 *$ & 0.040 \\
\hline Lymphocyte count (uL) & & $3481 \pm 2772.20$ & $3019 \pm 1739.49$ & $0.441 *$ & 0.664 \\
\hline Monocyte count (uL) & & $763 \pm 365.70$ & $488 \pm 155.14$ & $2.118^{*}$ & 0.047 \\
\hline Eosinophil count (uL) & & $184 \pm 166.71$ & $126 \pm 93.02$ & $0.947 *$ & 0.355 \\
\hline Basophil count (uL) & & $52 \pm 29.20$ & $42 \pm 26.35$ & $0.828 *$ & 0.418 \\
\hline Platelet count (uL) & & $254154 \pm 76375.00$ & $314444 \pm 110643.70$ & $-1.517 *$ & 0.145 \\
\hline Neutrophil to lymphocyte ratio & & $4.46(0.74-73.74)$ & $1.93(0.96-13.25)$ & $-0.902 \dagger$ & 0.367 \\
\hline Platelet to lymphocyte ratio & & $66.55(2.20-773.97)$ & $93.63(49.91-619.23)$ & $-0.568 \dagger$ & 0.570 \\
\hline Glucose (mg/dL) & & $173.15 \pm 51.46$ & $189.89 \pm 49.45$ & $-0.762 *$ & 0.455 \\
\hline Sodium (mmol/L) & & $139.00 \pm 6.15$ & $137.22 \pm 2.05$ & $0.830 *$ & 0.416 \\
\hline Potassium (mmol/L) & & $4.33 \pm 0.56$ & $4.56 \pm 0.56$ & $-0.953 *$ & 0.352 \\
\hline Blood urea nitrogen $(\mathrm{mg} / \mathrm{dL})$ & & $34.63 \pm 12.67$ & $30.86 \pm 12.13$ & $0.697 *$ & 0.494 \\
\hline Creatinin (mg/dL) & & $0.88(0.58-5.20)$ & $0.81(0.64-1.18)$ & $-0.768 \dagger$ & 0.442 \\
\hline Aspartate aminotransferase $(\mathrm{u} / \mathrm{L})$ & & $24(14-158)$ & $27.33(11.34-80)$ & $-0.167 \dagger$ & 0.867 \\
\hline Alanine aminotransferase $(\mathrm{u} / \mathrm{L})$ & & $18.51(10-132)$ & $23.86(13.63-45.49)$ & $-0.969 \dagger$ & 0.333 \\
\hline C-reactive protein $(\mathrm{mg} / \mathrm{dL})$ & & $16(0.01-250.77)$ & $6.76(0.83-33.56)$ & $-0.634 \dagger$ & 0.526 \\
\hline Duration of stay in ICU (day) & & $21(7-425)$ & $10(4-25)$ & $-2.173 \dagger$ & $\mathbf{0 . 0 3 0}$ \\
\hline Duration of stay in hospital (day) & & $28(12-425)$ & $19(5-31)$ & $-2.173 \dagger$ & $\mathbf{0 . 0 3 0}$ \\
\hline Glasgow Outcome Scale score & & $1(1-5)$ & $1(1-5)$ & $-0.639 \dagger$ & 0.523 \\
\hline \multirow[t]{2}{*}{ Mortality rate } & Survived & $3(13.6 \%)$ & $3(13.6 \%)$ & $0.282 \ddagger$ & 0.595 \\
\hline & Died & $10(45.5 \%)$ & $6(27.3 \%)$ & & \\
\hline
\end{tabular}

(*) Independent Samples t test; (†) Mann Whitney U test; and (†) Pearson’s chi-square test, $\mathrm{p}<0.05$ 
Table 3: Descriptive table for the demographic, radiological and biochemical findings of the SURVIVED and NONSURVIVED groups

\begin{tabular}{|c|c|c|c|c|c|}
\hline Variable & & $\begin{array}{c}\text { NON-SURVIVED } \\
\text { Mean } \pm \text { SD } / \\
\text { Median (min-max) } \\
\mathrm{n}(\%)\end{array}$ & $\begin{array}{c}\text { SURVIVED } \\
\text { Mean } \pm \text { SD/ } \\
\text { Median (min-max) } \\
\mathrm{n}(\%)\end{array}$ & $\mathbf{t} / \mathbf{Z} / \mathbf{X}^{2}$ & $\mathbf{p}$ \\
\hline Age (year) & & $59.56 \pm 20.36$ & $37.83 \pm 12.80$ & $2.420 *$ & 0.025 \\
\hline \multirow[t]{2}{*}{ Gender } & Male & $10(45.5 \%)$ & $3(13.6 \%)$ & $0.282 \ddagger$ & 0.595 \\
\hline & Female & $6(27.3 \%)$ & $3(13.6 \%)$ & & \\
\hline \multirow[t]{2}{*}{ Etiology } & ASH & $8(36,45)$ & $3(13.6 \%)$ & $0.000 \%$ & 1.000 \\
\hline & Stroke & $8(36,45)$ & $3(13.6 \%)$ & & \\
\hline \multirow[t]{2}{*}{ Comorbidity } & No & $9(40.9 \%)$ & $4(18.2 \%)$ & $0.196 \$$ & 0.658 \\
\hline & Yes & $7(31.8 \%)$ & $2(9.1 \%)$ & & \\
\hline Glasgow Coma Scale score & & $5(3-13)$ & $5.50(4-10)$ & $-0.782 \dagger$ & 0.434 \\
\hline Midline shift level (mm) & & $9.34 \pm 4.81$ & $9.25 \pm 3.92$ & $0.043^{*}$ & 0.966 \\
\hline \multirow[t]{2}{*}{ Pupillary dilatation } & No & $1(4.5 \%)$ & $0(0.0 \%)$ & $0.393 \$$ & 0.531 \\
\hline & Yes & $15(68.2 \%)$ & $6(27.3 \%)$ & & \\
\hline \multirow[t]{3}{*}{ Decision time of the DC } & Very early & $5(22.7 \%)$ & $3(13.6 \%)$ & $1.547+$ & 0.461 \\
\hline & Early & $3(18.8 \%)$ & $0(0.0 \%)$ & & \\
\hline & Late & $8(36.4 \%)$ & $3(13.6 \%)$ & & \\
\hline \multirow[t]{2}{*}{ DC site } & Left & $8(36.4 \%)$ & $3(13.6 \%)$ & $0.000 \%$ & 1.000 \\
\hline & Right & $8(36.4 \%)$ & $3(13.6 \%)$ & & \\
\hline DC area $\left(\mathrm{cm}^{2}\right)$ & & $97.50(50-116)$ & $90.50(82-116)$ & $-0.148 \dagger$ & 0.883 \\
\hline \multirow[t]{2}{*}{ Complication related to DC } & No & $9(40.9 \%)$ & $4(18.2 \%)$ & $0.196 \%$ & 0.658 \\
\hline & Yes & $7(31.8 \%)$ & $2(9.1 \%)$ & & \\
\hline Hemoglobin level (g/dL) & & $13.65 \pm 2.20$ & $14.37 \pm 2.30$ & $-0.672 *$ & 0.509 \\
\hline Leukocyte count (uL) & & $13842 \pm 6382.24$ & $15540 \pm 3900.74$ & $-0.605^{*}$ & 0.552 \\
\hline Neutrophil count (uL) & & $10474 \pm 6446.73$ & $9136 \pm 3841.83$ & $0.474^{*}$ & 0.641 \\
\hline Lymphocyte count (uL) & & $2577 \pm 1615.09$ & $5199 \pm 3112.22$ & $-2.618 *$ & 0.016 \\
\hline Monocyte count (uL) & & $557 \pm 234.63$ & $900 \pm 414.70$ & $-2.468 *$ & $\mathbf{0 . 0 2 3}$ \\
\hline Eosinophil count (uL) & & $131 \pm 125.11$ & $237 \pm 165.85$ & $-1.614^{*}$ & 0.122 \\
\hline Basophil count (uL) & & $44 \pm 26.80$ & $60 \pm 29.67$ & $-1.232 *$ & 0.232 \\
\hline Platelet count (uL) & & $240813 \pm 69018.08$ & $380167 \pm 78832.52$ & $-4.066^{*}$ & 0.001 \\
\hline Neutrophil to lymphocyte ratio & & $4.55(0.96-73.74)$ & $2.05(0.74-6.10)$ & $-1.622 \dagger$ & 0.105 \\
\hline Platelet to lymphocyte ratio & & $87.39(2.20-773.97)$ & $73.77(32.89-193.80)$ & $-0.663 \dagger$ & 0.507 \\
\hline Glucose (mg/dL) & & $187.69 \pm 53.06$ & $159.50 \pm 37.77$ & $1.185^{*}$ & 0.250 \\
\hline Sodium (mmol/L) & & $138.69 \pm 5.59$ & $137.17 \pm 2.23$ & $0.639 *$ & 0.530 \\
\hline Potassium (mmol/L) & & $4.32 \pm 0.36$ & $4.70 \pm 0.90$ & $-1.450^{*}$ & 0.162 \\
\hline Blood urea nitrogen $(\mathrm{mg} / \mathrm{dL})$ & & $35.47 \pm 12.99$ & $26.74 \pm 7.93$ & $1.529 *$ & 0.142 \\
\hline Creatinin (mg/dL) & & $0.80(0.58-5.20)$ & $0.83(0.68-1)$ & $0.000 \dagger$ & 1.000 \\
\hline Aspartate aminotransferase $(\mathrm{u} / \mathrm{L})$ & & $24.50(11.34-158)$ & $25.67(1930-80)$ & $-0.442 \dagger$ & 0.658 \\
\hline Alanine aminotransferase $(\mathrm{u} / \mathrm{L})$ & & $20.45(10-132)$ & $20.50(10.68-45.49)$ & $-0.295 \dagger$ & 0.768 \\
\hline C-reactive protein $(\mathrm{mg} / \mathrm{dL})$ & & $17.28(0.83-250.77)$ & $3.76(0.01-91.31)$ & $-1.180 \dagger$ & 0.238 \\
\hline Duration of stay in ICU (day) & & $18(5-425)$ & $14.50(4-28)$ & $-0.627 \dagger$ & 0.530 \\
\hline Duration of stay in hospital (day) & & $20(5-425)$ & $28(18-34)$ & $-0.627 \dagger$ & 0.530 \\
\hline Glasgow Outcome Scale score & & $1(1-1)$ & $3.5(2-5)$ & - & - \\
\hline
\end{tabular}

(*) Independent Samples t test; $(\dagger)$ Mann Whitney U test; and ( $\$$ ) Pearson’s chi-square test, $\mathrm{p}<0.05$ 
Table 4: Parameters that can predict the short-term prognosis, complication risk and mortality risk in patients with traumatic acute subdural hematoma or middle cerebral artery occlusion

\begin{tabular}{llccccc}
\hline $\boldsymbol{R O C}$-Curve test for complication risk & & & & & \\
\hline Group & Variable & Area & $\mathbf{p}$ & Cut-off value & Sensitivity & Specificity \\
\multirow{2}{*}{ STROKE-OP } & Leukocyte (uL) & 0.107 & $\mathbf{0 . 0 3 8}$ & $<8625$ & $75 \%$ & $86 \%$ \\
& Neutrophil (uL) & 0.107 & $\mathbf{0 . 0 3 8}$ & $<5750$ & $75 \%$ & $86 \%$ \\
\hline ROC-Curve test for mortality risk & & & & & \\
\hline Group & Variable & Area & $\mathbf{p}$ & Cut-off value & Sensitivity & Specificity \\
\multirow{2}{*}{ All patients } & Age (year) & 0.188 & $\mathbf{0 . 0 2 7}$ & $>37$ & $\% 67$ & $\% 88$ \\
& Platelet (uL) & 0.927 & $\mathbf{0 . 0 0 3}$ & $<291000$ & $\% 100$ & $\% 81$ \\
\multirow{2}{*}{ TASH-OP } & Lymphocyte (uL) & 0.000 & $\mathbf{0 . 0 1 4}$ & $<4910$ & $\% 87$ & $\% 100$ \\
& NLR & 0.958 & $\mathbf{0 . 0 2 5}$ & $>0.95$ & $\% 100$ & $\% 67$ \\
\hline \multirow{2}{*}{ STROKE-OP } & Age (year) & 0.917 & $\mathbf{0 . 0 4 1}$ & $>59$ & $\% 88$ & $\% 100$ \\
& Platelet (uL) & 0.083 & $\mathbf{0 . 0 4 1}$ & $<189000$ & $\% 88$ & $\% 100$ \\
\hline
\end{tabular}

Odds Ratio test for complication risk

$95 \% \mathrm{CI}$

\begin{tabular}{|c|c|c|c|c|}
\hline & Variable & Odds Ratio value & Lower & Upper \\
\hline All patients & Anisocoria & 1.75 & 1.21 & 2.54 \\
\hline
\end{tabular}

Odds Ratio test for mortality risk

\begin{tabular}{|c|c|c|c|c|}
\hline \multirow{2}{*}{\multicolumn{2}{|c|}{ Variable }} & \multirow[b]{2}{*}{ Odds Ratio value } & \multicolumn{2}{|c|}{ 95\% CI } \\
\hline & & & Lower & Upper \\
\hline All patients & Anisocoria & 1.40 & 1.07 & 1.84 \\
\hline \multicolumn{5}{|c|}{ Likelihood Ratio test for short-term prognosis } \\
\hline Group & Variable & $\mathbf{X}^{2}$ & \multicolumn{2}{|c|}{$\mathbf{p}$} \\
\hline \multirow{2}{*}{ All patients } & Age (year) & 11.479 & \multicolumn{2}{|c|}{0.022} \\
\hline & Platelet (uL) & 14.203 & \multicolumn{2}{|c|}{0.007} \\
\hline
\end{tabular}

ROC-Curve test, Likelihood Ratio test, and Odds Ratio test, $\mathrm{p}<0.05$.

\section{DISCUSSION}

Although it is reported that the survival rate of patients operated within 4 hours after trauma is $90 \%$, cohort studies from Canada, Poland, USA, and England reported that the timing of the surgery cannot predict the outcome (9). On the other hand, previous studies have reported that predictors of favorable outcomes for all patients with TBI indicate younger age, higher GCS scores, and the absence of associated lesions indicating damage to the underlying cortex such as contusion or intraparenchymal hemorrhage $(4,16)$. Many authors reported that the mortality rate in the stroke patients who underwent DC was shown to be significantly reduced compared to the medical treatment group (17-20). In the present study, the comorbidity rate was found to be $40.9 \%$, the rate of complication related to DC was found to be $36.4 \%$. Interestingly, the complication rate was negatively correlated with the time elapsed for DC, leukocyte, and neutrophil count values. Although low level of leukocyte and neutrophil counts could predict the risk of complication related to DC, Odds Ratio test results demonstrated that presence of anisocoria was associated with a high risk of complication. With these findings, it could be said that presence of the anisocoria could be used as a marker in predicting the complication risk. Besides, it was thought that the possibility of complications related to DC in stroke patients may be 
higher when the DC was performed early or when the leukocyte and neutrophil count was found lower before surgery. It was argued that the duration of stay in ICU and the duration of stay in the hospital might be prolonged in patients with TASH when complications occurred.

The mortality rate in each group was found to be $77.2 \%$. With these results, it could be said that DC could not reduce the mortality risk either in stroke patients or TASH patients. Although both the TASH patients underwent surgery in a very early period and the stroke patients underwent in the late period, the mortality rates of these groups were found to be similar, and time elapsed for DC was not correlated with the prognosis. Furthermore, neither the time elapsed for DC nor the MLS values were directly correlated with the GOS scores or mortality rates. On the other hand, it was seen that the time elapsed for DC prolonged and serum potassium levels could be high in conditions of comorbidity, whereas leukocyte count and serum AST levels might be lower.

It was observed that mortality risk may increase in patients with advanced age and low platelet counts. Leukocyte and monocyte counts could be found lower in elderly patients, while serum BUN values were found to be high. With these findings, it was thought that the mortality risk of the patients could be directly related to age and platelet counts while leukocyte and monocyte counts and serum BUN levels might be indirectly related. Thus, it was suggested that age, leukocyte, monocyte, and platelet counts, and serum BUN levels could be markers in predicting mortality risk in patients who underwent DC. However, regression analysis revealed that no parameters belonging to the patients could be the "best marker" to predict mortality risk. Yet, Odds ratio test results demonstrated that presence of the anisocoria could be weakly associated with the mortality risk.

Correlation test results revealed that prognosis of the patients was directly related to the lymphocyte and platelet counts, whereas neutrophil count, NLR, and serum CRP levels could be indirectly related and these parameters could be markers for short-term prognosis. However, at the end of the regression analysis, it was determined that only age and platelet count value could be the "best markers" to predict the short-term prognosis of these patients.

Correlation test results obtained from TASH-OP group revealed that short-term prognosis of these patients could be worse when they had low lymphocyte, monocyte, eosinophil, and basophil counts and high NLR and PLR values. In addition, it was thought that the mortality risk of these patients might be high when the lymphocyte count was low. In conclusion, it was argued that lymphocyte count and NLR level value could be direct markers, and PLR level, monocyte, eosinophil, and basophil counts could be indirect markers in predicting the short-term prognosis of patients with TASH. Moreover, it was hypothesized that lymphocyte count and PLR level, monocyte, eosinophil, and basophil counts could be indirect markers in predicting mortality risk in these patients. Furthermore, Odds ratio test results showed that presence of anisocoria could increase the complication risk in a patient with TASH.

On the other hand, it was assumed that the short-term prognosis might be worse in patients in the STROKEOP group if the age was advanced and serum potassium level, platelet count, neutrophil count, and NLR values were low. Furthermore, it was thought that mortality risk might be high if the serum potassium level, platelet count, neutrophil count, and NLR values were low. Thus, it was argued that age, platelet count, and serum potassium level could be direct markers in predicting short-term prognosis, and neutrophil count and NLR values could be indirect markers. Furthermore, it was thought that platelet count and serum potassium level could be a direct marker and neutrophil count and NLR values could be indirect markers in predicting mortality risk. 
This study had some shortcomings. First, in this singlecenter study, the number of patients remained low. Secondly, the ICP monitor could not be administered to patients due to economic limitations (5). Third since this study was conducted to investigate the possible effects of routine biochemistry laboratory parameters on the prognosis and mortality risk, advanced analysis of neuroradiological imaging findings were not included in this study. Finally, because only the short-term outcomes of the patients were examined, the long-term results or quality of life of the patients were not addressed. However, at the end of this study, it was concluded that the results obtained from the study are interesting and can shed light on future studies.

At the end of this study, it was argued that lymphocyte, platellet and neutrophil counts, NLR, and serum CRP levels could be assumed as markers for short-term prognosis of patients who underwent decompressive craniectomy. Additionally, it was suggested that age, leukocyte, monocyte, and platelet counts, and serum BUN levels could all be predictors of mortality risk in these patients. Finally, it could be said that leukocyte and neutrophil count results, GCS score value, side of the DC, MLS level value, and presence of the anisocoria could be used as markers in predicting the complication risk.

Conflict of Interest: The authors declare that they have no conflict of interests. They also declare that they have not engaged in any financial relationship with any company whose product might be affected by the research described or with any company that makes or markets a competing product.

Support and Acknowledgment: None.

Researchers' Contribution Rate Statement: The authors declare that they have contributed equally to the article. Concept/Design: MÖ, BS, UY, AÖ, SA, BB; Analysis/interpretation: MÖ, BS, UY, AÖ, SA, BB; Data Collection: MÖ, BS, UY, AÖ, SA, BB; Writer: MÖ, BS, UY, AÖ, SA, BB; Critical Review: MÖ, BS,
UY, AÖ, SA, BB; Supervision: MÖ, BS, UY, AÖ, SA, BB.

Ethics Committe Aproval: Kırıkkale University Ethics Committee of Non-Interventional Clinical Research, date: 26.08.2020; issue number: 2020.08.03.

Informed Consent: Informed consent was obtained from all individual participants or their parents who were included in this study.

\section{REFERENCES}

1. Wu S, Yuan R, Wang Y, Wei C, Zhang S, Yang X et al. Early prediction of malignant brain edema after ischemic stroke. Stroke. 2018;49(12):2918-27.

2. Aarabi B, Hesdorffer DC, Ahn ES, Aresco C, Scalea TM, Eisenberg HM. Outcome following decompressive craniectomy for malignant swelling due to severe head injury. $J$ Neurosurg. 2006;104(4):469-79.

3. Lazaridis C, Czosnyka M. Cerebral blood flow, brain tissue oxygen, and metabolic effects of decompressive craniectomy. Neurocrit Care. 2012;16(3):478-84.

4. Tian R, Liu W, Dong J, Zhang J, Xu L, Zhang B et al. Prognostic predictors of early outcomes and discharge status of patients undergoing decompressive craniectomy after severe traumatic brain injury. World Neurosurg. 2019;126:e101e108.

5. Zweckberger K, Juettler E, Bösel J, Unterberg WA. Surgical aspects of decompression craniectomy in malignant stroke: review. Cerebrovasc Dis. 2014;38(5):313-23.

6. Bakar B, Sumer MM, Tekkok IH. Decompressive craniectomy for intractable intracranial hypertension. J Clin Anal Med. 2012;3(4):383-7.

7. Kim KT, Park JK, Kang SG, Cho KS, Yoo DS, Jang DK et al. Comparison of the effect of decompressive craniectomy on different neurosurgical diseases. Acta Neurochir (Wien). 2009;151(1):21-30. 
8. Kalayci M, Aktunç E, Gül S, Hanci V, Edebali N, Cagavi $\mathrm{F}$ et al. Decompressive craniectomy for acute subdural hematoma: an overview of current prognostic factors and a discussion about some novel prognostic parameters. J Pak Med Assoc. 2013;63(1):38-49.

9. Altaf I, Shams S, Vohra AH. Role of surgical modality and timing of surgery as clinical outcome predictors following acute subdural hematoma evacuation. Pak J Med Sci. 2020;36(3):412-5.

10. Daou B, Kent AP, Montano M, Chalouhi N, Starke RM, Tjoumakaris $\mathrm{S}$ et al. Decompressive hemicraniectomy: predictors of functional outcome in patients with ischemic stroke. J Neurosurg. 2016;124(6):1773-9.

11. Teasdale G, Jennett B. Assessment of coma and impaired consciousness. A practical scale. Lancet. 1974;2(7872):81-4.

12. McMillan T, Wilson L, Ponsford J, Levin H, Teasdale G, Bond M. The Glasgow outcome scale40 years of application and refinement. Nat Rev Neurol. 2016;12(8):477-85.

13. Chung J, Bang OY, Lim YC, Park SK, Shin YS. Newly suggested surgical method of decompressive craniectomy for patients with middle cerebral artery infarction. Neurologist. 2011;17(1):11-5.

14. Ho MY, Tseng WL, Xiao F. Estimation of the craniectomy surface area by using postoperative images. Int J Biomed Imaging. 2018;2018:5237693.

15. Karibe H, Hayashi T, Hirano T, Kameyama M, Nakagawa A, Tominaga T. Surgical management of traumatic acute subdural hematoma in adults: a review. Neurol Med Chir (Tokyo). 2014;54(11):88794.

16. Pullicino PM, Alexandrov AV, Shelton JA, Alexandrova NA, Smurawska LT, Norris JW. Mass effect and death from severe acute stroke. Neurology. 1997;49(4):1090-5.
17. Agarwalla PK, Stapleton CJ, Ogilvy CS. Craniectomy in acute ischemic stroke. Neurosurgery. 2014;74(Suppl 1):S151-62.

18. Hofmeijer J, Kappelle LJ, Algra A, Amelink GJ, van Gijn J, van der Worp HB et al. Surgical decompression for space-occupying cerebral infarction (the Hemicraniectomy After Middle Cerebral Artery infarction with Life-threatening Edema Trial [HAMLET]): a multicentre, open, randomised trial. Lancet Neurol. 2009;8(4):326-33.

19. Jüttler E, Schwab S, Schmiedek P, Unterberg A, Hennerici M, Woitzik J et al. Decompressive Surgery for the Treatment of Malignant Infarction of the Middle Cerebral Artery (DESTINY): a randomized, controlled trial. Stroke. 2007;38(9):2518-25.

20. Vahedi K, Vicaut E, Mateo J, Kurtz A, Orabi M, Guichard JP et al. Sequential-design, multicenter, randomized, controlled trial of early decompressive craniectomy in malignant middle cerebral artery infarction (DECIMAL Trial). Stroke. 2007;38(9):2506-17. 